\title{
GST AND ITS IMPACT ON VARIOUS SECTORS
}

KEY WORDS: Gst, Sunrise Sectors, Tax Exemption, Implementation

\section{Sai Swetha Student-BBA Garden City University Bangalore. \\ Sneha Kanade* Assistant Professor Garden City University Bangalore *Corresponding Author}

The idea of GST was conceived during the tenure of the prime minister Shri Atal Bihari Vajpayee. It took sixteen years to implement the taxation. Various aspects of GST were examined by working group of officials' representatives from state and center. The reports specifically on exemption and thresholds, taxation of services and taxation of inter-State supplies. Lack of political consensus, the bill failed after suspension. The implementation of GST invited a mixed response from the country. The paper attempts to analyses the GST implementation in 5 sectors. It also aims to suggest model to boost the few sunrise sectors.

\section{INTRODUCTION:}

\subsection{INTRODUCTIONTOTAXATION:}

Taxation, imposition of compulsory levies on individuals are entities by governments. taxes are levied all most every country of the world, primarily to raise revenue for government expenditures, all though they serve other purposes as well (from debts to paying for public services like loans, libraries, military etc..). Taxes are collected based on tax payer earnings and property.

\subsection{TAX AND ITS TYPES:}

Tax is an amount of money that a citizen have to the government so that it can pay for the public services. When a person or company is taxed they have to pay a part of their income or profit to the government. When goods are taxed, a percentage of their price has to be paid to the government. Taxes help to raise the standard of living in a country.

According to Bastbal, "A tax as a compulsory contribution to the wealth of a person or body of person for the service of public power.

According to prof. Seligman, "A compulsory contribution from a person to the government to defray the expenses incurred in the common interest of all, without reference to special benefits conferred".

Taxes are broadly divided into two categories:

1. Direct tax

2. Indirect tax

\subsubsection{DIRECT TAX}

It is a tax levied directly on a tax payer who pays it to the Government and cannot pass it on to someone else.

Some of the important direct taxes imposed in India areIncome tax, Corporate tax, Capital gains tax etc..

- INCOME TAX: It is imposed on an individual who falls under the different tax brackets based on their earning or revenue and they have to file an income tax return every year after which they will either need to pay the tax or be eligible for a tax refund.

- CAPITAL GAINS TAX: Any profit or gain that arises from the sale of a 'capital asset' is a capital gain. This gain or profit is comes under the category 'income', and hence you will need to pay tax for that amount in the year in which the transfer of the capital asset takes place. This is called capital gains tax, which may be short term or long term.

- CORPORATE TAX: This tax is paid by the companies registered under company law in India on the net profit that it makes from the businesses. It is taxed at a specific rate has prescribed by the income tax at subject to the changes in the rates every year by the IT department.

\section{ADVANTAGES OF DIRECT TAXES:}

Direct taxes do have certain advantages for a country social and economic growth to name a few.

1. It curbs inflation

2. Social and Economic balance

\section{DISADVANTAGES OF DIRECT TAXES:}

Direct taxes come with a hand full of disadvantages. But, the very time consuming procedures of filing tax returns is a hard task.

\subsubsection{INDIRECT TAXES:}

It is a tax levied by the Government on goods and services and not on the income, profit or revenue of an individual and it can be shifted from one taxpayer to another.

Earlier, an indirect tax meant paying more than the actual price of a product bought or a service acquired. And there was a myriad of indirect taxes imposed on tax payers.

The following are some of the indirect taxes that were earlier imposed in India-

- SERVICE TAX : It was imposed on gross or aggregate amount charged by the service provider on the recipient

- SALES TAX: This tax was paid by the retailer, who would then shifts the tax burden to customer by charging sales tax on goods and service.

- VALUE ADDED TAX: It was collected on the value of goods or services that were added at each stage of their manufacture or distribution and then finally passed on to the customer.

\section{ADVANTAGES OF INDIRECT TAXES: 1. CONVENIENT}

The main advantage is that it is easy for the state authority to gather this tax since they are direct upon collection from the factory, port, saving effort and time.

\section{EASY COLLECTION}

Gathering these taxes is an automatic function performs when purchasing and selling goods and services

\section{DISADVANTAGES OF INDIRECT TAXES:}

\section{RESTRICT FREETRADE:}

Free trade may be restricted due to high export and import duties

\section{BURDEN FOR POOR PEOPLE:}

Indirect taxes reduce the saving capacity of poor people. So, these taxes are not suitable for households and new income groups.

\section{INFLATIONARY:}

Higher tax rate increases the price of the product which may

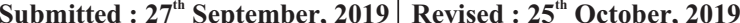

Accepted : $17^{\text {th }}$ November, 2019 Publication : $15^{\text {th }}$ December, 2019 
lead to inflation.

\section{- NEWLY IMPLEMENTED INDIRECT TAX (GST):}

GST is a highly regarded tax system for the country. It is amongst the latest indirect tax systems operating under the constitution of India. The importance of this taxation regime lies in the fact that it covers under itself various other indirect taxes operating inside the country. This tax regime has been brought in mark a change in economy of the country.

\subsection{GOODS AND SERVICES TAX (GST):}

With the implementation of GST, we have already witnessed a number of positive changes in the fiscal domain of India. The various taxes that were mandatory earlier are now obsolete, thanks to this new reformed indirect tax. Not just that, GST is making sure the slogan "One Nation, One Tax, One Market" becomes the reality of our country and not just a dream.

With the dawning of the GST, the biggest relief so far is clearly the elimination of the 'cascading effect of tax' or the 'tax on tax' quandary.

Cascading effect of tax is a situation where in the endcustomer of any goods or service has to bear the burden of the tax to be paid on the previously calculated tax and as a result would suffer an increased or inflated price.

\subsubsection{HISTORY OF GST:}

First time GST was introduced in France in the year 1954 and subsequently GST law was implemented more than 160 countries like Germany, Italy, UK, Canada etc. In India the idea of GST was proposed by Atal Bihari Vajpayee in 1999 and a committee was set up under the leadership of Asim Das Gupta, the finance minister of West Bengal to design a GST model. It was supposed to be implemented from $1^{\text {st }}$ April 2010 but due to political issues it could not come into force. In May 2016 the constitutional amendment bill for GST was passed by Lok Sabha and $1^{\text {st }}$ April 2017 was decided as dead line to implement. Finally the goods and service tax was launched at midnight on $1^{\text {st }}$ July 2017 by the president of India, Pranab Mukherjee and Prime minister of India, Narendra Modi. In India, Canadian model of GST has been adopted. As the present GST replaced the existing complicated indirect tax structure.

\section{REVIEW OF LITERATURE}

1. N. Ramya (2017) said that GST is a comprehensive tax levy on manufacture, sale and consumption of goods and services GST is termed as a biggest tax reform in India. The purpose of GST is to replace indirect taxes with single comprehensive tax, bringing it all under single umbrella. She stated that by reducing the tax burden the competitiveness of Indian products in International market is expected to increase and there by development of the nation.

2. Dr. Vivek Sharma(2019) stated that the applicability of GST emphasized the self assessment processor but there were so man complexities and it increased the possibility of errors while filing the return therefore he said that the need of trained and skilled person with updated GST subject knowledge was needed for providing service regarding return and other GST work and the provision of GST audit becomes necessary for the transaction above certain limit

3. Harpreete Singh (2019) said that beyond the shadow of any doubt, successful adoption of GST has been vital contributor to the exemplary ascends in India's ranking. GST replaced VAT, service tax, excise duty and many other indirect taxes. Hence, GST regime ensures single registrations for the sake of indirect taxes, thereby is in the business startup. As per The Hindu, 77\% of CFO's admitted the GST impacted there businesses positively and aided in the, is of doing business.
4. Madesh H.R and Kavya Dechamma K.M. (2010) stated that though GST has made a various change in taxation system, it may find difficult for economy to cope up with the changes but has definitely a good future for the economy in the later years. GST is said to increase the standard of living that indirectly improves the financial system of the nation there by improving the Indian economy. Thus GST has a greater impact in developing country like India. Agricultural sector GST has the positive effect in the agricultural sector as all tax will be reimbursed under the tax rate. Then the sales movement of the states between the states will be easy and hassle free, which will save time and destructive good transport.

5. Nitin Kumar (2014) studied, "Goods and Service Tax - A Way Forward" and concluded that implementation of GST helps in removing economic distortion by current indirect tax system and expected to encourage unbiased tax structure which is indifferent to geographical locations.

6. R.Vasanthagopal (2011) studied, "GST in India: A Big Leap in the Indirect Taxation System" and concluded that switching to GST from current complicated indirect tax system in India will be a positive step in booming Indian economy. Success of GST will lead to its acceptance by more than 140 countries in world and a new preferred form of indirect tax system in Asia also.

7. Jaiprakash (2014) in his research paper mentioned that the GST at the Central and the State level are expected to give more relief to industry, trade, agriculture and consumers through a more comprehensive and wider coverage of input tax set off and service tax set off, subsuming of several taxes in the GST and phasing out of CST. Responses of industry and also trade have been indeed encouraging. Thus GST offers us the best option to broaden our tax base and we should not miss the opportunities to introduce it when the circumstances are quite favorable and economy is enjoying steady growth with only mild inflation.

\section{OBJECTIVES:}

- To study about the needs and the Importance of the GST to Indian economy.

- To study about the impact of GST on various sectors in Indian economy.

- To provide suggestions and recommendations regarding GST.

\section{RESEARCH METHODOLOGY:}

This study is purely descriptive in nature. The data for the study were gathered from the secondary sources such as journals, blogs, articles published online and offline on newspapers and websites.

\section{DISCUSSIONS AND RECOIMMENDATIONS TAXES SUBSUMED UNDER THE GST: ONTHE STATE LEVEL: \\ - State excise duty \\ - Additional excise duty \\ - Service tax \\ - Countervailing duty \\ - Special additional custom duties}

\section{AT THE CENTRAL LEVEL:}

- Sales tax

- Entertainment tax

- Central sales tax

- Purchase tax

- Luxury tax

\section{FEATURES OF GST:}

- It will have two components, central GST levied by the central government and state GST levied by states.

- A two-rate structure will be adopted. It means lower rate 
for necessary items and goods of basic importance and standard rate for goods in general. There will also be a special rate for precious metals and a list of exempted items.

- Overlapping of tax, tax on tax will be eliminated with GST.

- Both goods and services are taxed in same manner in chain of supply till they are reached to consumer. They are not distinguished under GST.

\section{BENEFITS OF GST:}

- GST provides comprehensive and wide coverage of input credit set off, you can use service tax credit for the payment of tax on sale of goods etc.

- Uniformity of tax rates across the states

- Ensure better compliance due to aggregate tax reduces.

- Price of goods is expected to reduce in the long run as a benefit of less tax burden would be passed on the consumer.

\section{STATUS BEFORE GST :}

Before implementation Of Goods and Service Tax (GST) Indian taxation system was a farrago of central, state and local area levies. Central Government had the power to levy taxes on good manufacturing and provision of services. Whereas State Government was empowered to levy taxes on Agriculture, and good distribution and reselling.

Hence various complications like non-availability of cross utilization of taxes i.e. utilization of Central Government levies against State Government levies and vice versa, leading to cascading of taxes; Formation of separate economic spheres on account of varied VAT laws in the country with different rates and tax practices were faced.

\section{IMPACT OF GOODS AND SERVICES TAX :}

GST has brought in "one nation one tax" system, but its effect on various industries is slightly different. The first level of differentiation will come in depending on whether the industry deals with manufacturing, distributing and retailing or is providing a service.

\section{- IMPACT OF GST ON INDIAN ECONOIMY}

Goods and Services Tax is extremely useful for the economy of India for a long term basis. The reason for the benefit of the Goods and Services Tax is due to uniformity of taxes. It merges all the indirect taxes which were prevailing in India during the Value Added Tax (VAT).

Goods and Services Tax helps the business sector to grow and to become strong by bringing transparency. When the business sector will flourish it will help in creating further employment which will ultimately lead to reducing the burden of the tax.

GST have a consistent scheme for the tax or the goods and services across India, i.e. $0 \%, 5 \%, 12 \%, 18 \%$ and $28 \%$.The tax rate of some goods or products is different from the rest such as gold, precious stones and semi -precious stones. Things such as luxury cars, tobacco, carbonated beverages, etc, are subjected to $22 \%$ of the additional charges.

Micro, Small and Medium Enterprises (MSME's) has suffered some sort of complications with new tax regime i.e. GST. All the Micro, Small, and Medium Enterprises (MSME's) are suffering problems to conduct their business as there is a requirement of registration in every state from where MSME's are formulating a supply. GST is helping the MSME's in developing the ability for the purpose of maintaining the account book. Maintenance of the account book will ultimately help the enterpriser to get a loan from any bank or financial institution. This will help them to increase their business. They will now borrow the money from the formal sector and will no longer rely on informal sector for obtaining the loan. The country like India really demands a strong MSME's which helps in creating more employment.

GST helps in controlling the tax evasion. Permanent Account Number (PAN) which is issued by the income tax department is linked with the GST i.e. GSTN. This helps in establishing a relationship between indirect taxes and direct taxes. This ultimately aid or support in reducing the tax to an enormous extent. During the regime prior to the GST, there were many cases of tax evasion. When the taxpayers disclose their turnover under the indirect tax law and direct tax both differed from each other, which gives a path to the evasion of tax.

After implementation of the GST, there is an expectation of an increase in the tax Gross Domestic Product (GDP) ratio. The expectation is that the basis points will increase up to thirty in the fiscal year of 2019-2020 each and $2020-2021$. This was stated by the table of medium - term expenditure framework (MTEF) in the lower house i.e.Lok Sabha.The data bases of the indirect tax and direct tax are linked together; it helps the data analytical tools to remove all the inconsistency and also helps the authorities of revenue to take a mandatory action.

Summing up the whole, an increase in the ratio of GDP will overall help in lowering the rate of tax in India. GST will help the Indian economy on a long term basis.

\section{- IMPACT ON IRON AND STEEL INDUSTRIES}

Materials like iron and steel are very useful and utilized in everyday life. GST has a positive impact on the iron and steel and material made of these. Kitchen utensils that are useful in day to day life become cheaper than the previous. Utensils like pan, stainless steel cooker and many more are now charged with $12 \%$ of GST. It is charged $7 \%$ less than the current tax laws. There are benefits for all steel - related companies as there is $5 \%$ low tax on all the large inputs used by them under the GST.These inputs are iron ore, coal, etc.

All the industries relating to the Iron and Steel are getting benefits with the introduction of the GST. There is an expectation that will help in further more benefits by reducing or lowering the input tax and logistics.

\section{- IMPACT ON ENTERTAINMENT INDUSTRY:}

Before the enforcement of GST, the entertainment section pays many taxes. They are not limited to one tax. They pay the central tax, state level tax and also tax imposed by the local authorities. But, when GST was imposed they were liable to pay only one tax.

GST was ranging between $18 \%$ to $28 \%$.The tax rate was totally dependent upon kinds of the Entertainment Services.

\section{THINGSWITHIN THE $18 \%$ GST}

- Circus

- Television and DTH services

- Theatre

- Movie Tickets (Tickets costing up to Rs.100 have GST 12\% and tickets costing more than Rs. 100 have GST 18\%)

\section{THINGSWITHINTHE $28 \%$ GST}

- Racing

- Casinos

- Amusement parks

- Movie events

- Sporting event

\section{- IMPACT OF GST ON CUSTOIMERS:}

GST has given an overall profit to the entertainment sector. The tax on the movie ticket was $30 \%$ and there was $20.5 \%$ of the VAT along with the service on the foods which a person buys from the theatre. But, after GST, a tax imposed on the 
ticket was $28 \%$ and tax on the foods in the cinemas was changed at $18 \%$.

But here we use different results relating to the impact of GST on the entertainment sector. Reasons for various consequences are:

- Low tax on entertainment service in some states

- No tax on entertainment services in some states

When GST was imposed in these states, they suffer a rise in the tax on entertainment sector. However, it was low for those where the tax on entertainment services was high. But, if we compare, GST was quite low in comparison to the tax system i.e.VAT and Service Tax, which was prevailing before GST.

State also has the power to include or charge Local Body Tax (LBT) in addition to the tax which was discussed above under GST. Local bodies also have the power to impose a further change, under GST, on the entertainment services in their respective area.

\section{- IMPACT OF GST ON HOTEL ANDTOURISM:}

Income generated from the hotel and tourism plays a vital role in the Indian economy. They help in increasing the GDP of India. This is why every State Government keeps on promoting the tourism of their state by various advertis ements. Rates of GST differ for the hotels because of the following tariffs.

- If the tariffs range Rs. 1000 and less than 1000 there will be no GST.

- If the tariff range between Rs.1000 to Rs.2500 then GST will be $12 \%$

- If the tariff range between Rs.2500 to Rs.7500 then GST will be $18 \%$

- If the tariff range between Rs. 7500 then GST will be $28 \%$

There is $5 \%$ GST on the person who operates the tour. But there is an expectation that as the Goods and Services Tax (GST) had lower the tax rate on the operators of the tour the price of the tour also show the down graph.

\section{- IMPACT OF GST ON SUPPLY CHAIN}

\section{SUPPLY CHAIN:}

It is type of web or chain which lies between company and its supplier for production and distribution of a particular product to an ultimate buyer. It represents the process that was taken from receiving the product from its original character to the consumer.

The supply of chain is necessary for the purpose of proper running of trade and business which is producing and circulating the product and material. There is some impact on this sector after the implementation of GST which are:-

- Enhancement and advancement of the stock points

- Reduction in the channel inventories

\section{FOOD GRAINS}

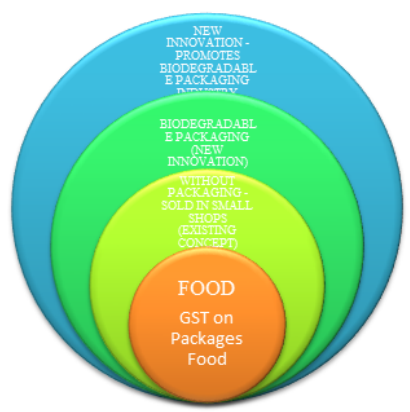

Food grains are very basic requirement of mankind. In Indian context it is staple food of the people. As per the current provision of GST for food grains, there is no GST if sold loose like in Kirana Shops. However the food grains are packaged and branded then the brand would have to pay $5 \%$ GST. The suggested GST model talks about waiving off GST for foods packaged in biodegradable packaging. This helps promote the biodegradable packaging and also boosts the biopackaging industry.

\section{EDUCATION}

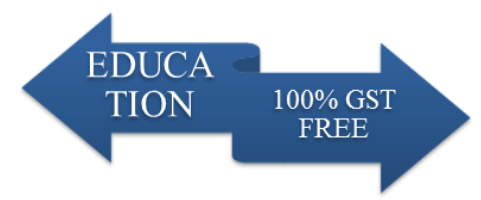

Education is a major agenda in the current five-year plan; hence the education needs to be free. This primarily would include skill-based education, vocational training etc.

\section{CONCLUSION:}

GST has been welcomed by maximum citizens and business people. The ease of trade has been established by one trade one tax principle. However there has been scope for improvement as there are multiple situations that arise and need solutions. There are two possibilities which have been mentioned above after analysis of 5 sectors. The options are implementable and could help certain industries to grow.

\section{REFERENCES :}

1. https://www.britannica.com/topic/taxation

2. https://www. google $\mathrm{com} / \mathrm{search}$ ?q=taxation \&oq=taxation\&aqs=chr ome..69i57j69i60j69i59j69i60j69i59.5187j0j7\&client=ms-andr oid-samsunggj-revl \& sourceid $=$ chrome-mobile\&ie $=$ UTF- 8

3. https://www.quora.com/What-is-taxation-1

4. https://cleartax.in/s/direct-indirect-taxation-india-explained

5. https://cleartax.in/s/capital-gains-income

6. https://www.coverfox.com/personal-finance/tax/indirect-tax/

7. https://benefits-drawbacks.blogspot.com/2018/07/disadvantages-ofindirect-taxes.html

8. https://www.researchgate.net/publication/320892175_GST_AND_ITS IMPACT_ON_VARIOUS_SECTOR

9. https://www.karvy.com/growth-hub/tax/advantages-disadvantages-of-gstin-india/

10. https://www.deskera.in/gst-impact-across-sectors/

11. https://www.taxmanagementindia.com/visitor/detail_rss_feed.asp? ID $=1226$ 